\title{
Place-based leadership and public service innovation
}

Robin Hambleton

Professor of City Leadership, Cities Research Centre, University of the West of England, Bristol and Director of Urban Answers

\section{Starting points}

This think-piece explores three related themes:

- Innovation in public service reform needs better leadership

Top-down approaches to the improvement of public service performance - 'target models' - are of limited effectiveness when enhanced performance requires innovation. The promotion of innovation requires forms of leadership that are not commonplace in the UK. Improved leadership is needed at local, regional and national levels

- Place-based (or civic) leadership is weak in the UK

The government's 'Total Place' reform efforts (of 2009) are a step in the right direction as they focus on the needs of a 'place', not the needs of an organisation. But, when compared with other countries, local government in the UK lacks 'clout'. New thinking is needed regarding the nature of place-based leadership - what it involves, how to encourage it and how to underpin it. In particular, the UK needs to develop approaches to civic leadership that promote local innovation in dealing with societal problems.

\section{- Universities can help develop local innovative capacity}

Universities, provided they see themselves as 'civic' or 'engaged' universities, can make a significant contribution not just to the promotion of innovation (defined broadly) in their area, but also in assisting with the development of place-based leadership. Universities in other countries, notably the USA, make a much more significant contribution to local leadership than is the case in the UK. Some leaders in UK higher education understand this argument, and recent moves to advance the cause of university 'public engagement' need to be supported and expanded. 
The paper discusses each of these three themes in turn and six 'propositions' are made in the text arising from the discussion (see italics). These 'propositions' are restated in a closing section and provide the basis for a consideration of a range of possible initiatives and/or studies.

\section{1) Innovation in public services}

'Innovation' in public service leadership and management is now very much on the public policy agenda. NESTA has made an important contribution - for an early example see Mulgan (2007). The Government White Paper, Innovation Nation, argued that 'Innovation is essential to the UK's future economic prosperity and quality of life' (H M Government 2008) and support for 'innovation' has gathered pace. The Whitehall Innovation Hub, led by Dr Su Maddock, has, for example, acted as a spur to fresh thinking within Whitehall (Maddock 2008, 2009). And innovation is receiving increased attention in local government circles. The collection of essays, co-sponsored by the IDeA and NESTA, on More than good ideas: the power of innovation in local government (Parker 2009) provides a positive example.

The challenges now facing public sector leaders - a severe recession, enormous pressures on public finances, climate change - have boosted the importance of innovation in public policy. Enhancing the capacity of organisations and places to innovate should no longer be seen as a 'good idea'. Rather, developing the innovatory capacity of society is now heartland business for public servants. Few politicians and public service leaders now believe that carrying on in broadly the same way is a viable option for UK public services.

My own definition of innovation is 'Doing something nobody told you to do' (Hambleton 2009a). This is because, by definition, when you innovate you invent something new. Nobody could have told you about it beforehand. It also follows that you can have 'bad' innovation - or, more positively, experiments that do not succeed - as well as 'good' innovation - that is, changes that bring about demonstrable benefits for different stakeholders. Accepting this proposition has profound implications for those in civic leadership positions - both nationally and locally. Ministers and local politicians, civil servants and local government officers and, indeed, public service managers across the board, will need to shed some fairly well entrenched attitudes if innovation in public services is to flourish.

This is because the old 'command and control' or 'target driven' approach to leadership needs to be jettisoned. In simple terms, fostering a culture of innovation requires leaders to forget about creating management regimes that seek 'conformance', and start fostering problem solving behaviour that breaks new ground in order to enhance public service 'performance'. Shifting from 'conformance' models to 'performance' models of leadership is demanding 
because it requires - in the UK context at least - a deep shift in prevailing attitudes ${ }^{1}$.

Proposition 1): Innovation requires a shift from 'conformance' to 'performance' approaches to leadership

A second theme we now discuss concerns the differential readiness of different organisations and places to take on the innovation agenda ${ }^{2}$. Recent research on local governance in the UK, for example, suggests that developing the innovative capacity of local authorities - whatever their form and size - deserves more active consideration. To ensure that reform efforts relating to innovation are well suited to the local context it is helpful to think of an innovation curve in local governance. First developed in 1998 the notion of an innovation curve suggests that the readiness of different localities to take on the innovation challenge varies considerably (Hambleton and Holder 1998). This work identified three kinds of local authority in the UK context and these ideas may also apply in other countries - see Figure 1.

Figure 1. The innovation curve 1998

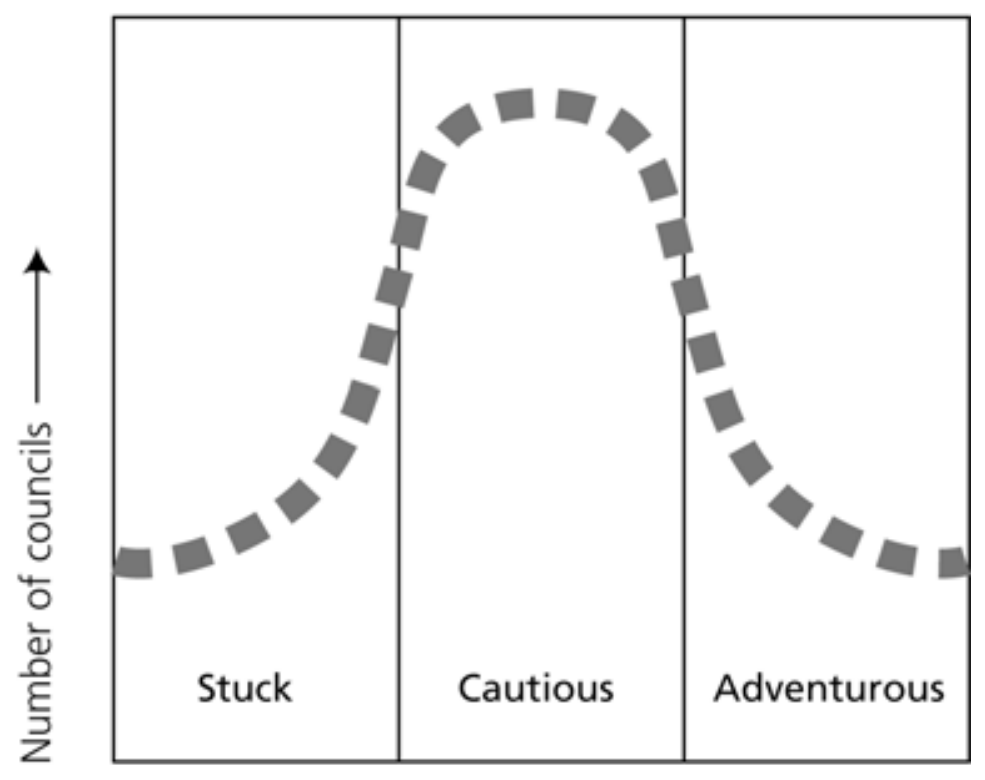

Adaptive capacity of the council

'Adventurous' councils were eager to exploit opportunities available to them. They set demanding aims for themselves, and welcomed the chance to compete (in the UK context) for 'Beacon status'. Most councils, it was suggested at the time, could be described as 'cautious'. They tended to adopt a 'wait and see' approach, and moved to adopt new approaches only after taking account of the experience of the pioneering councils.

\footnotetext{
${ }^{1}$ Having lived in other countries, including two spells in the USA, I take the view that this challenge is particularly noticeable in the UK

2 The discussion that follows draws heavily on a recent research report for the Local Authority Research Council Initiative (LARCI) (Hambleton et al 2009).
} 
The term 'stuck' was used, perhaps unkindly, to describe councils who were furthest back on the innovation curve. These authorities were, for a variety of reasons, resistant to change. They tended to be backward-looking and seemed intent on either ignoring or attacking the modernisation agenda. The 1998 article acknowledged that this framework was a simplification - for example, different parts of the same authority could be at different points on the innovation curve. The analysis did, however, highlight two points that are still relevant today.

First, councils are not at the same starting line when it comes to their capacity to innovate. Councils, and this is a point well recognised by the Improvement and Development Agency (IDeA) for local government over the years, at different points on the innovation curve need different kinds of support and encouragement.

Second, more attention needs to be given to the emotions of councillors and officers. Winning the intellectual argument for change is not enough. While the literature on 'emotional intelligence' is relatively young, it does at least offer the insight that emotions matter (Goleman 2002; Sashkin and Sashkin 2002; Heifetz and Linksy 2002). Leaders who manage their own emotions appear to be better equipped to understand the emotions and feelings of others. Leadership involves change and successful leaders inevitably generate opposition. It follows that they need to be both sensitive to the feelings of others but also resilient in the face of opposition.

Fast forward ten years and the picture (in the UK at least) is rather different see Figure 2.

Figure 2. The innovation curve 2008

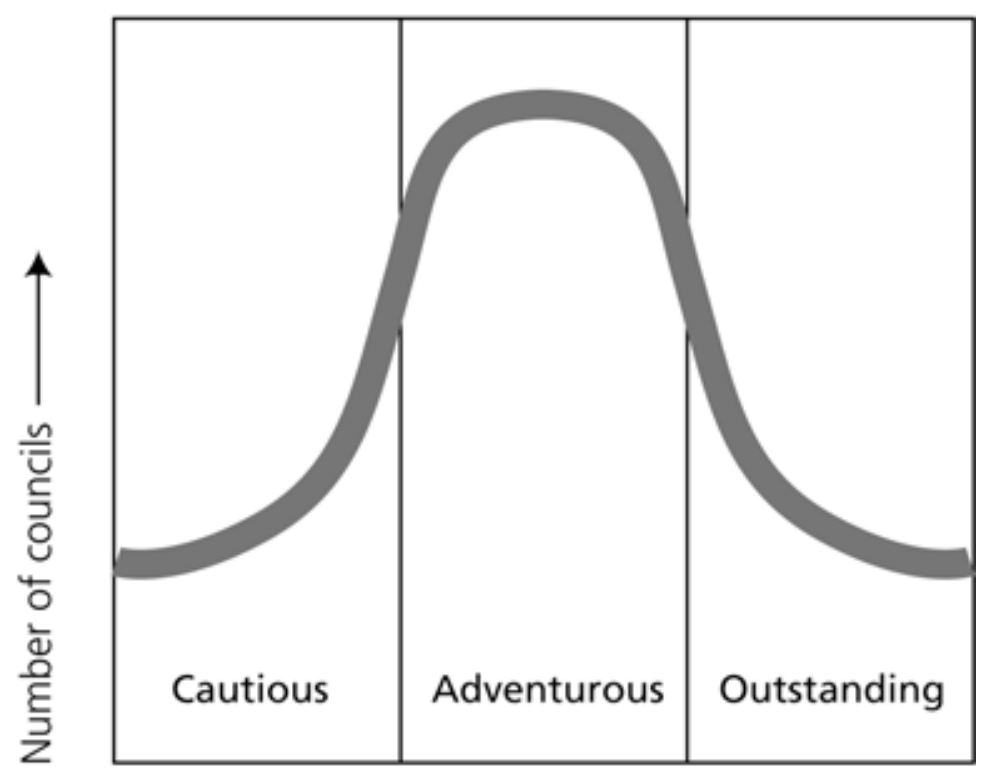

Adaptive capacity of the council 
The least innovative councils can now be described as 'cautious' (Hambleton and Holder 2008). Given the improvements of the last decade, no council in the UK is now 'stuck' in the sense used in Figure 1. This is progress, but the cautious councils are followers - it is unlikely that they will startle their peers by breaking entirely new ground.

The second group in Figure 2 is described as 'adventurous'. This could, perhaps, be an optimistic view. However, there is evidence, as mentioned earlier, to suggest that a good deal of innovation is taking place in UK local government (Parker 2009). But being adventurous is now no longer enough. The truly innovative councils of today have raised their sights beyond the targets suggested by national performance regimes and are striving to be 'outstanding'. By this I mean operating at an exceptional level when compared with the other localities internationally. While I recognise that it is a dramatic simplification of a more complex reality I suggest, in Figure 3, that the innovation curve is in the process of moving in an international direction.

Figure 3. The innovation curve 1998-2008

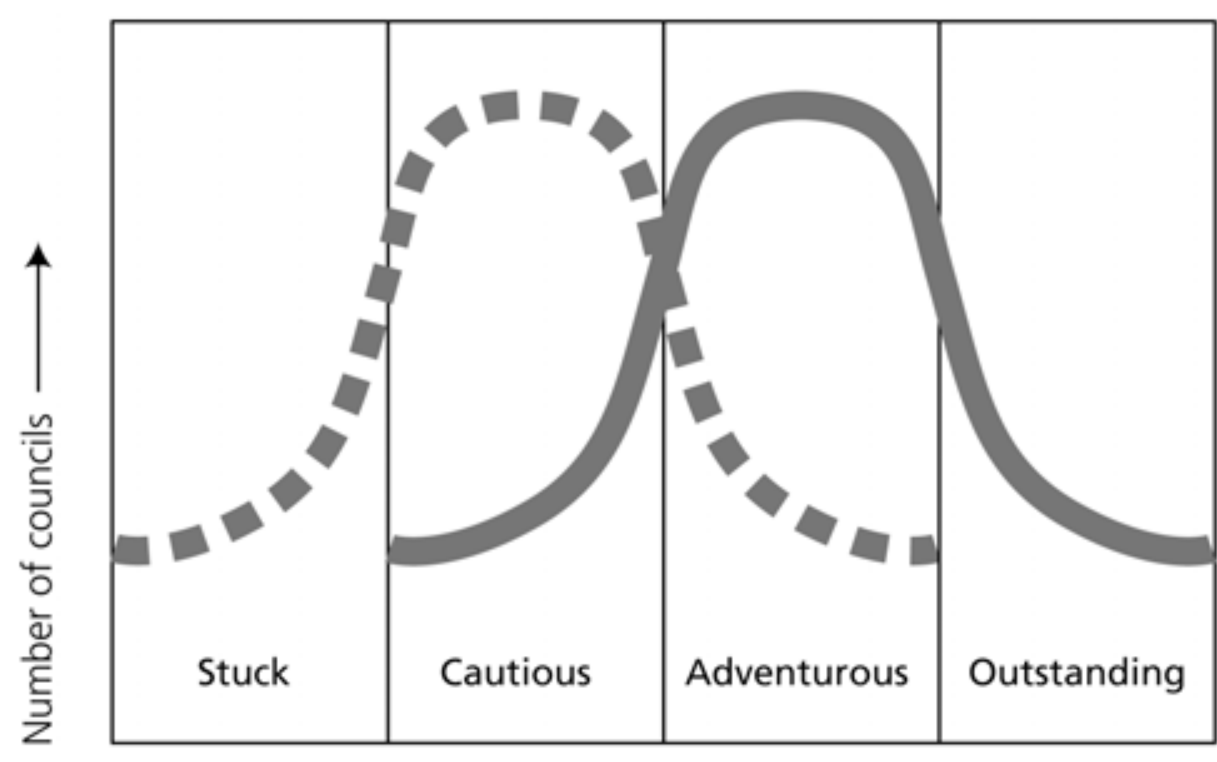

Adaptive capacity of the council

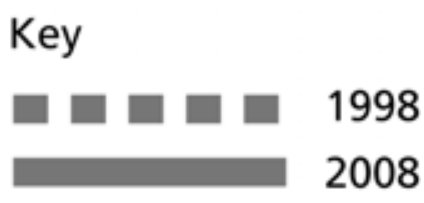

In changing times it is difficult to over estimate the importance of keeping innovation 'front of stage' in the thinking of local leaders and managers. Several lessons emerge from this brief review. First, following the established literature on management innovation, we can note that: 'Innovation is essentially about learning and change and is often disruptive, risky and costly' 
(Tidd et al $2005 \mathrm{p}$ 468). Successful innovation usually requires receptive and supportive leadership. Second, approaches to the leadership of innovation need to be tuned to the situation leaders find themselves in. The innovation curve can help leaders take account of the differential readiness of different organisations to innovate, including their 'emotional readiness'. Third, and this is a larger point that needs further elaboration, concerns the importance of embedding international thinking more firmly into UK public policy. Crossnational learning can provide a valuable stimulus to innovation and it is interesting to note that international city-to-city policy exchange around innovation themes is rising dramatically (Hambleton 2008).

Proposition 2): Leaders wishing to inspire bold and effective innovation should tailor their approach to the level of 'innovation readiness' they encounter

Proposition 3): Public service leaders should be less 'UK-centric' and should embed learning from abroad into their day to day practice

\section{2) Strengthening civic leadership}

I have defined leadership as 'Shaping emotions and behaviour to achieve common goals' (Hambleton 2007 p174). Civic or place-based leadership can be defined broadly to embrace all leadership activity that serves a public purpose in a given locality. In simple terms we can distinguish leadership that is 'place-based' from other kinds of leadership that are 'place-less'.

Civic leadership is 'place-based' leadership - meaning that those exercising decision-making power have a concern for the communities living in a particular 'place'. Some of the most powerful decision-makers in modern society are 'place-less' leaders in the sense that they are not concerned with the geographical impact of their decisions. Following Stiglitz, who draws on Putnam, I take the view that an unfettered market, especially in the context of globalisation, can destroy communities (Stiglitz 2006). There is now a substantial body of literature on 'social capital' and the role that it plays in fostering a caring society (Putnam 2000; Gilchrist 2004). There are different kinds of social capital and sometimes this capital can be used to exclude groups - the creation of social capital will not necessarily reduce socioeconomic inequalities. However, with the right kind of civic leadership - of which more in a moment - it may be possible to encourage the bridging of social ties between different social groups.

In my view, successful leadership is inspirational and collaborative. This implies a wide range of activities aimed at generating both new insights and new ways of working together - it prizes respect for the feelings and attitudes of others as well as a strong commitment to collaboration (Svara 1994). As Su Maddock observes:

'Being clever is not enough. A range of talents or aptitudes is required by contemporary public leaders.... The ability to collaborate is becoming more and more significant within organisations and localities undergoing transformation' (Maddock 2009 p17). 
Civic leaders are found in the public, private, and community/voluntary sectors and they operate at many geographical levels - from the street block to an entire sub region and beyond. Three kinds of civic leadership can be distinguished as shown in Figure $4:^{3}$

Figure 4. Civic leadership

- a conceptual framework

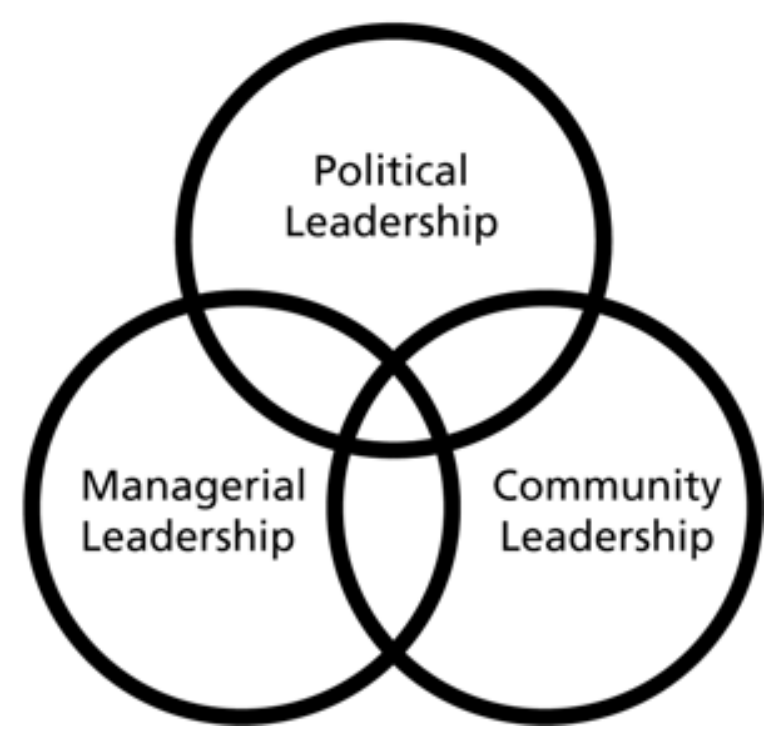

- Political leadership - referring to the work of those people elected to leadership positions by the citizenry. These are, by definition, political leaders. Thus, all elected local councillors are political leaders, although we should acknowledge that different councillors carry different roles and responsibilities and will view their political role in different ways.

- Managerial leadership - referring to the work of public servants appointed by local authorities, central government and third sector organisations to plan and manage public services, and promote community wellbeing. These officers bring professional and managerial expertise to the tasks of local governance.

- Community leadership - referring to the work of the many civicminded people who give their time and energy to local leadership activities in a wide variety of ways. These may be community activists, business leaders, voluntary sector leaders, figures in

\footnotetext{
${ }^{3}$ This framework was first developed in work I carried out for the Royal Commission on the Governance of Auckland in 2008 (Hambleton 2009b) and was further developed in a recent report for the Local Authority Research Council Initiative (LARCI) (Hambleton et al 2009).
} 
religious organisations, higher education leaders and so on. Particularly important here is the potential contribution to civic leadership of an independent and engaged voluntary and community sector.

These roles are all important in cultivating and encouraging public service innovation and, crucially, they overlap. The areas of overlap between these different realms of leadership can be thought of as innovation zones - areas providing many opportunities for innovation. This is because different perspectives are brought together within these zones and this can enable active questioning of established approaches.

It can be claimed that effective civic leadership in the coming period is likely to involve leadership behaviour that spans the boundaries between these three realms of civic leadership. Moreover, this approach takes it as read that inspirational leadership can emanate from any of the three realms of civic leadership, and innovation is likely to emerge through a conversation or series of conversations between them, in the spaces of overlap. Leadership capacity in modern society is dispersed. Our systems of local governance need to respect and reflect that diversity if decisions taken in the public interest are going to enjoy legitimacy. Further, more decentralized approaches both across localities and within each realm of civic leadership can empower informal leaders to be part of the dialogue.

I would highlight - as it is often overlooked - the importance of public officials in stimulating creative solutions to local problems. In the US context Nalbandian (1991) has emphasised the importance of professional managers identifying, understanding and working with the values of their local communities. And in more recent work he has shown how professionals can play a crucial role in promoting community involvement and, what he describes as, 'civic discovery' (Nalbandian 2007).

The conceptual framework set out in Figure 4 is, of course, a drastic simplification of a more complex reality. For example, the relative power of the different realms varies by locality and this would imply different sized circles, whereas I have kept them all the same size. Moreover, the realms shift in influence over time. There are also competing interests within each realm. Even so the framework provides a helpful way of examining the nature of civic or place-based leadership. It draws attention to the important role leadership can have in fostering innovation and it emphasises the importance of leadership through collaboration.

Proposition 4): Civic or place-based leadership involves bringing together actors from the three different realms of leadership

Proposition 5): The areas of overlap between the different realms of leadership - the 'innovation zones' - provide promising opportunities for innovation to take place 


\section{3) UK universities - the sleeping giants of civic leadership}

In the USA public universities play an important civic leadership role ${ }^{4}$. It is not just that they see themselves as 'anchor institutions' within their localities the very raison d'etre of a US public university is much broader than the typical UK university. Without embarking on a long discussion it can be claimed that UK universities tend to focus on two activities: teaching and research. In the US the focus is more likely to be on three or even four core aims: teaching, research, public service and, in some situations, economic development.

A recent 'provocation' for NESTA on Re-inventing the civic university examines the suggestion that UK universities can, indeed, learn from US experience (Goddard 2009). John Goddard argues that universities in the UK have a civic duty to engage with wider society on the local, national and global scales, and to do so in a manner which links the social to the economic spheres. In higher education circles there is now the beginnings of a recognition that universities can and should be doing much more to contribute to societal problem solving in the areas where they are located. This, I argue, can have enormous benefits for the research practiced by universities as well as the learning experiences of students, not to mention the benefits for local stakeholders (Hambleton 2009c)

The idea of university 'public engagement' should not be seen as a simple 'add on' to the existing functions of universities. Rather it can help redefine the nature of the scholarship carried out in universities. Here I follow Ernest Boyer, the ground-breaking US higher education reformer. In 1990 he executed an enormously influential review of the evolution of conceptions of scholarship in US higher education and concluded: 'What we are faced with, today, is the need to clarify campus missions and relate the work of the academy more directly to the realities of contemporary life... We proceed with the conviction that if the nation's higher learning institutions are to meet today's urgent academic and social mandates, their missions must be carefully redefined and the meaning of scholarship creatively reconsidered' (Boyer 1990 p. 13).

On the basis of his analysis Boyer suggests that the work of the professoriate might be thought of as having four separate, yet overlapping, functions:

- The scholarship of discovery comes closest to what is meant when academics speak of 'research'. The scholarship of discovery contributes not only to the stock of human knowledge but also to the intellectual climate of the university. The advancement of knowledge can, in Boyer's view, generate an almost palpable excitement in the life of an educational institution.

\footnotetext{
${ }^{4}$ I draw here on my experience as Dean of the College of Urban Planning and Public Affairs at the University of Illinois at Chicago (2002-07)
} 
- The scholarship of integration gives meaning to isolated facts, putting them in perspective. By making connections across disciplines, placing the specialties in larger context, illuminating data in a revealing way the scholarship of integration can bring new insight to bear on original research. Boyer argues that interdisciplinary and integrative studies, long on the boundaries of academic life, are moving to the center, responding both to new intellectual questions and to pressing human problems.

- The scholarship of application asks how can knowledge be responsibly applied to consequential problems? And can social problems themselves define an agenda for scholarly investigation? Boyer is at pains to point out that the scholarship of application is different from the traditional notion of 'service' in US higher education. Good citizenship activities - such as supporting youth clubs and the like - are meritorious but, to be considered as scholarship, service activities need to tie directly to one's special field of knowledge. Boyer envisages a two way process involving a dynamic dialogue with partners outside the campus - a process in which external partners help to shape the scholarly agenda.

- The scholarship of teaching is concerned with the learning process and the creation of a common ground of intellectual commitment. Great teachers stimulate active, not passive, learning and encourage students to be critical, creative thinkers long after their college days are over.

Boyer is quick to point out these four categories are tied inseparably together. In my view Boyer's vision of scholarship takes us forward as it recognizes the diversity of the challenges facing higher education as well as the diversity of talent within the professoriate. It also acknowledges that academics may prioritize different aspects of scholarship at different stages in their careers.

For the purposes of this Think-piece we can note that there is enormous potential for the expansion of what Boyer calls 'engaged scholarship' in UK higher education. The National Centre for Public Engagement (NCCPE), based in Bristol, is fostering developments that can assist universities wanting to move in this direction but there is much to $\mathrm{do}^{5}$.

Proposition 6) UK universities could be much more active players in local civic leadership and, in particular, in the promotion of local innovation

\section{Conclusions - six propositions relating to leadership and innovation}

\footnotetext{
${ }^{5}$ The National Coordinating Centre for Public Engagement (NCCPE) is co-sponsored by the University of the West of England and the University of Bristol. More information:

www.publicengagement.ac.uk
} 
In this final section the six 'propositions' referred to in the text are restated. They can provide the basis for a discussion of possible initiatives and/or studies.

Proposition 1): Innovation requires a shift from 'conformance' to 'performance' approaches to leadership

Proposition 2): Leaders wishing to inspire bold and effective innovation should tailor their approach to the level of 'innovation readiness' they encounter

Proposition 3): Public service leaders should be less 'UK-centric' and should embed learning from abroad into their day to day practice

Proposition 4): Civic or place-based leadership involves bringing together actors from the three different realms of leadership

Proposition 5): The areas of overlap between the different realms of leadership - the 'innovation zones' - provide promising opportunities for innovation to take place

Proposition 6) UK universities could be much more active players in local civic leadership and, in particular, in the promotion of local innovation

Copyright Robin Hambleton November 2009

\section{About the author}

Robin Hambleton is Professor of City Leadership in the Cities Research Centre, Faculty of Environment and Technology, University of the West of England, Bristol and Director of Urban Answers.

He has wide experience of city leadership and change management in local government in the UK and in other countries. He has been an Adviser to UK local government ministers, a consultant to Select Committees of the UK House of Parliament, and has written national guidance documents for councils in England, Wales and Scotland. He is the author of ten books and over 300 articles and was the founding President of the European Urban Research Association (EURA). His latest book, co-edited with Jill Simone Gross, is Governing Cities in a Global Era. Urban Innovation, Competition and Democratic Reform (Palgrave, 2007). From 2002-2007 he was Dean of the College of Urban Planning and Public Affairs at the University of Illinois at Chicago. 


\section{References}

Gilchrist A. (2004) The well-connected community. Bristol: The Policy Press.

Goddard J. (2009) Re-inventing the civic university. Provocation 12. October. London: NESTA

Goleman D. (2002) The New Leaders. London: Times Warner.

H. M. Government (2008) Innovation Nation. Department for Innovation, Universities and Skills. Cm 7345. March. London: author.

Hambleton R. (2007) 'New leadership for democratic urban space' Chapter 12 in Hambleton R. and Gross J. S. (eds) Governing Cities in a Global Era. Basingstoke and New York: Palgrave.

Hambleton R. (2008) International Insights. Learning about innovation from other countries. Series of five articles published in Municipal Journal (April June) and in longer form on the IDeA website: www.idea.gov.uk/international

Hambleton R. (2009a) 'Civic leadership and public service innovation' pp 103109 in Parker S. (ed) More than good ideas: the power of innovation in local government. London: IDeA/NESTA.

Hambleton R. (2009b) Civic Leadership for Auckland: An International Perspective pp 515-552 in Royal Commission (2009) Auckland Governance Report. Vol 4. Auckland: Royal Commission on Auckland Governance Available at: www.royalcommission.govt.nz

Hambleton R. (2009c) 'Get out and join the city life', Times Higher Education, 1 October, p24.

Hambleton R. and Holder A. (1998) 'The price of change', Municipal Journal, 2 October, pp 20-21.

Hambleton R. and Holder A. (2008) 'A decade of innovation', Municipal Journal, 2 October, pp 32-33.

Hambleton R., Howard J., Buser M. and Taylor M. (2009) International Insights on Civic Leadership and Public Service Innovation. London:

Communities and Local Government/LARCI.

Heifetz R. A. and Linksy M. (2002) Leadership on the Line. Boston: Harvard Business School Press.

Maddock S. (2008) Creating the Conditions for Public Innovaton. London: National School of Government.

Maddock S. (2009) Change you can believe in. The Leadership of Innovation. London: National School of Government. 
Mulgan G. (2007) Ready or not? Taking innovation in the public sector seriously. Provocation 3. April. London: NESTA.

Nalbandian J. (1991) Professionalism in Local Government: Transformations in the Roles, Responsibilities and Values of City Managers. San Francisco: Jossey-Bass.

Nalbandian J. (2007) 'Professionals and the conflicting forces of administrative modernization and civic engagement' pp 189-198 in Hambleton R. and Gross J.S. (eds) (2007) Governing Cities in a Global Era. Basingstoke and New York: Palgrave.

Parker S. (ed) (2009) More than good ideas: the power of innovation in local government. London: IDeA/NESTA.

Putnam R. D. (2000) Bowling alone: The collapse and revival of American community. New York: Simon and Schuster.

Sashkin M. and Sashkin M. G. (2002) Leadership that matters. San Francisco: Berrett-Kohler.

Stiglitz J. (2006) Making Globalization Work. London: Allen Lane.

Svara J. H. (ed) (1994) Facilitative Leadership in Local Government. Lessons from Successful Mayors and Chairpersons. San Francisco: Jossey-Bass.

Tidd, J., Bessant J. and Pavitt K. (2005) Managing Innovation. Chichester: John Wiley and Son. 